(C) 1987 ISIJ

$$
\begin{aligned}
& \text { グロー放電発光分光法によるめつき層 } \\
& \text { およびクロメート皮膜の定量分析 }
\end{aligned}
$$

$$
\text { 鈴木堅市* ・山崎修一*・森隆 } * 2 \cdot \text { 大坪孝至*3 }
$$

\title{
Quantitative Analysis of Electroplated Films and Chromate Film by Glow Discharge Spectrometry
}

\author{
Ken-ichi SUZUKI, Shuichi YAMAZAKI, Takashi MORI and Takashi OHTSUBO
}

\section{Synopsis:}

Factors which determine the Grim glow discharge characteristics, sputtering rate and emission yield were studied in order to obtain quantitative depth profiles of surface films on steel sheets using the glow discharge spectrometry (GDS).

1) The sputtering rate of a specimen (with a constant composition) depends on the product of the effective discharge voltage and the courrent, being indifferent of the Ar pressure and the discharge modes (constant voltage, constant current and constant power).

2) The emission yield (within the abnormal glow discharge reange) on the three modes increases depending on the Ar pressure.

3) Some matrix effects are observed in the emission yield of zinc and iron for $\mathrm{Zn}-\mathrm{Fe}$ alloy plating. The emission yield, therefore, should be corrected according to approximate alloy composition in order to obtain accurate results.

4) GDS can also be applied for the analysis of very thin layers, such as chromate film on the top of tin plates. The coefficient of variance of the analysis of $\mathrm{Ni}, \mathrm{Su}$ and $\mathrm{Cr}$ (chromate) layers (the total thickness $100 \mathrm{~nm}$ ) is less than $5 \%$.

\section{1. 緒言}

グリムランプを利用したグロー放電発光分析法 (Glow Discharge Spectrometry, 以下 GDS と略す) はバルク 分析のみならず，表而分析手法としても種々の特長をも ち, Zn 系介金めつき鋼极の管理分析を中心にこの数年 急速に普及してきたＧDSで得られるスパッタリング 時間に対する元素の発光スペクトル強度の情報（I-T 曲 線）を，スパッ夕媣さと元素濃度との関係で表された走 量的デー夕 (C-D 曲線) に変換することは，I:業的な 管理分析はもとより, 材料の開発, 研究にとつても重要 である。

GDSによるZn 系介金めつき層の定量分析法として 㛟量線法 ${ }^{122}$ ，光强度樍分法 ${ }^{3)-5)}$ がすでに策用化されて いるが，放電の基碟的特性は必ずしも十分解明されてい ない，GDSに扔ける発光は，Arイオンによつてスパッ 夕された粒子（原子，分子，イオン）が $\mathrm{Ar}$ のプラズマ
中で励起され，基底状態に戻る際に起こる光放山現象で ある. 分析面の組成がダイナミックに変化する染さ方们 分析に打いては，放電条件を一定に保つことが必ずしも 容易でない，マトリックス組成の変化による放電条件の 変動が、スパッ夕速度や発光収率（スパッ夕粒子の光放 出確摔）にどのような影響を与えるか， Zn-Fe 合金め つき材を使つて検討した。また，GDSのより薄い皮膜 の起量分析への適用を目的に，薄目付ぶりき抄よびクロ メート皮膜の分析を試みた。

\section{2. 実}

\section{験}

\section{$2 \cdot 1$ 装置}

実験には西独 RSV 社製 ANALYMAT-2504 型 GDS

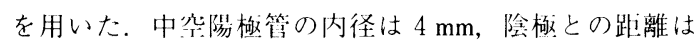
約 $0.2 \mathrm{~mm}$ とした。放電管内への $\mathrm{Ar}$ の供給はマスフ ローコントローラーにて流量制御し (100 $500 \mathrm{ml} / \mathrm{min})$, あらかじめ測定された $\mathrm{Ar}$ 流量と比的と関係曲線から

昭利 61 年 4 月 8 H受付 (Received Apr. 8, 1986)

* 新H本製鉄(株) 分析研究センター (Analysis Research Lab., Nippon Steel Corp., 1618 Ida Nakahara-ku Kawasaki 211)

*2（株）十鉄テクノリサーチ（Nippon Steel Techno Research)

*3 新H本製鉄 (株) 分析研究センター T博 (Analysis Research Lab., Nippon Steel Corp.) 
Table 1. Chemical compositions of samples.

(a) Zn-Fe alloy plated layers

\begin{tabular}{c|cc}
\hline Sample & Coating weight $\left(\mathrm{g} / \mathrm{m}^{2}\right)$ & Fe $(\mathrm{wt} \%)$ \\
\hline $\mathrm{A}$ & 18.7 & 82.1 \\
$\mathrm{~B}$ & 17.4 & 65.3 \\
$\mathrm{C}$ & 15.1 & 44.5 \\
$\mathrm{D}$ & 18.6 & 22.4 \\
E & 18.1 & 10.5 \\
F (Upper) & 3 & 85 \\
(Lower) & 25 & 15 \\
\hline
\end{tabular}

(b) Sn plated layers
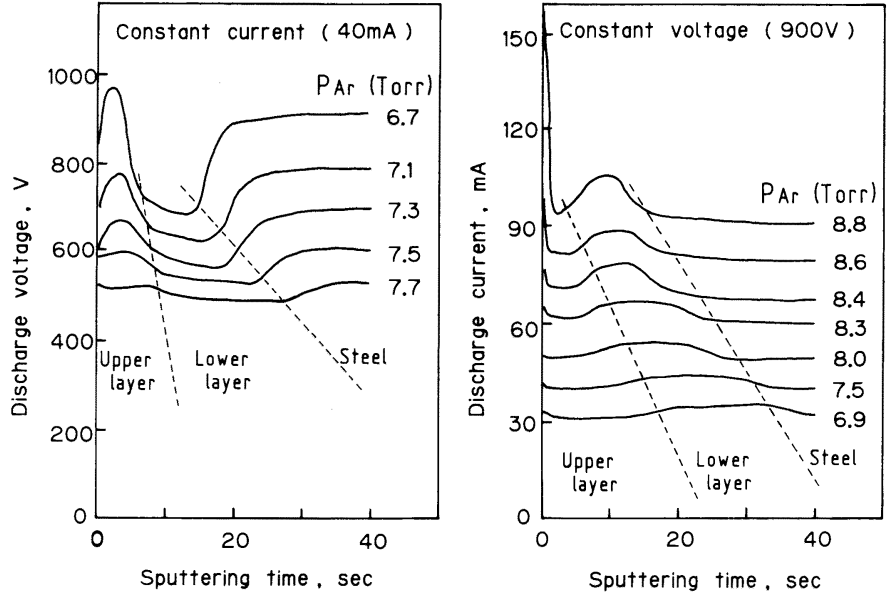

Fig. 1. Variation of discharge voltage and discharge current during depth analysis of $\mathrm{Zn}-\mathrm{Fe}$ alloy double layered plate.

求めた值を放電管内の $\mathrm{Ar}$ 压とした。分光器はマルチ

Table 2. Analytical lines.

チャンネル型で，おのおのの元素のスペクトル線強度を 光電子増倍管で検出し，マルチプレクサーを介して 5 $500 \mathrm{~ms}$ の間隔でソード M243 パーソナルコンピュー ターに採取した。なお，放電中の電流および電压もマル チプレクサーを介して同時にモニターした。

\section{$2 \cdot 2$ 供試材}

放電特性へのマトリックス効果を検討するための試料 として, 冷延鋼板に $\mathrm{Zn}-\mathrm{Fe}$ 合金（Fe 含有量 $10 \sim 80 \%$, 目付量的 $18 \mathrm{~g} / \mathrm{m}^{2}$ ) を単層電気めつきしたものと, $\mathrm{Zn}-\mathrm{Fe}$ 合金二層めつき材を用いた．薄めつき材は平滑 仕上げのぶりき用原板に Sn を電気めつきしたものであ るが, $\mathrm{Ni}$ による前処理，めつき後のリフロー処理（約 $\left.240^{\circ} \mathrm{C}\right)$ やクロメート処理を行つたものを用いた。めつ き層の目付量は, 酸溶解後原子吸光分析法にて求めた (Table 1). めつき層の酸溶解にあたつては, 下地鋼板 からの Feの溶解による影響のないことを確認した.

\section{$2 \cdot 3$ 実験方法}

GDS の放電は定電流, 定電庄および定電力の三種類 のモードで行い, 皮膜のスパッ夕速度とスペクトル線強 度を測定し，これらの放電条件（電流, 電圧抢よび $\mathrm{Ar}$ 压力）依存性を検討した。なお，皮膜のスパッ夕所要時 間は皮膜成分のスペクトル線強度が $1 / 2$ に減衰するまでに

\begin{tabular}{c|ccc}
\hline Sample & $\mathrm{Sn}\left(\mathrm{g} / \mathrm{m}^{2}\right)$ & $\mathrm{Ni}\left(\mathrm{g} / \mathrm{m}^{2}\right)$ & $\mathrm{Cr}\left(\mathrm{g} / \mathrm{m}^{2}\right)$ \\
\hline $\mathrm{G}$ & 0.84 & 0.009 & 0.019 \\
$\mathrm{H}$ & 0.69 & 0.012 & 0.014 \\
$\mathrm{I}$ & 0.80 & 0.032 & 0.012 \\
$\mathrm{~J}$ & 0.56 & 0.150 & - \\
$\mathrm{K}$ & 1.12 & 0.200 & 0.030 \\
$\mathrm{~L}$ & 0.60 & & \\
\hline
\end{tabular}

要する時間とし, 皮膜の中央近傍のスペクトル線強度を 皮膜成分の発光強度とした. GDSの測定条件および測 定した元素のスペクトル線を Table 2 に示した.

\section{3. 放電特性の $\mathrm{Ar}$ 圧，マトリックス組成依存性}

GDS における電流-電圧曲線は, Ar 压および試料 (陰 極）組成によつて異なる ${ }^{677)}$. したがつて哚さ方向で組 成の变化する試料の分析においては，一定のAr压で放 電しても定電流放電では電压が, 定電圧放電では電流が, また定電力放電ではその両方が試料組成の変化に伴つて 変動する．Fig. 1 は，Zn-Fe 合金二層めつき鋼板を表 面から地鉄までスパッ夕した際に放電特性が変化する様 子を示したものである.より安定した放電が得られると いう点からは, 低電厈領域での定電流放電, あるいは低 電流領域での定電圧放電が有利といえる.しかし, GDS による表面分析の定量化にあたつては，放電の電 
流，電压の安定性よりも，マトリックス組成が変化する ことによつてスパッ夕速度とスペクトル線強度がどのよ うに変化するか，この闭者の関係を把握することが重要 になる。

元素 $i$ のスペクトル線 $\lambda$ の強度 $I_{i(\lambda)}$ は，プラズマ中 の $i$ 元素の量, すなわちマトリックス中の濃度 $C_{i}$ とス パッ夕速度 $v$ の積に比例する（1 式）。

$$
I_{i(\lambda)}=\oint_{(\lambda)} \cdot Y_{(\lambda)} \cdot C_{i} \cdot v
$$

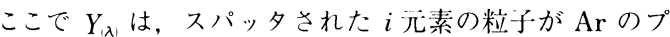
ラズマ中で励起され，基底状態に戻る際に光 $(\lambda)$ を放 出する確率であり， $\oint_{(\lambda)}$ はこの入の検出効率 (装置定数) である， $Y_{(\lambda)}$ を直接求めることが困難なため， $\oint_{(\lambda)}$ を固 定して求めた $Y_{(\lambda)}$ の相対值 $R_{(\lambda)}(2$ 式）を，本法ではス ペクトル線 $\lambda の$ 発生収率（Emission yeild）と表現した。

$$
R_{(\lambda)}=\oint_{(\lambda)} \cdot Y_{(\lambda)}
$$

$R_{\lambda}$ は実験的には（3）式から求めることができるが, この值は，単位重量の元素がスパッ夕された際のスペク トル線の積分強度になる。

$$
R_{i \lambda}=I_{i(\lambda)} / C_{i} \cdot v
$$

\section{$3 \cdot 1$ Ar 圧と放電特性}

$\mathrm{Zn}-\mathrm{Fe}$ 合金一層めつき材を使つて $\mathrm{Ar}$ 压を更に広い 範囲（4１5 Torr）で変化させ，おのおのの放電モード における発光特性およびスパッ夕速度を検討した。まず， おのおのの放電モードに抢ける Ar 压と，下層めつき層 の中央部での放電電流，電压の関係を Fig. 2 に示す. $\mathrm{Ar}$ 圧の上昇とともに, 笔電流放電では電圧が減小し, 定電圧放電では電流が堌大する。一方，定電力放電では 上記二つの現象が同時に起こるが，その变動の割合は前 二つの放電モードに比較して緩やかである.

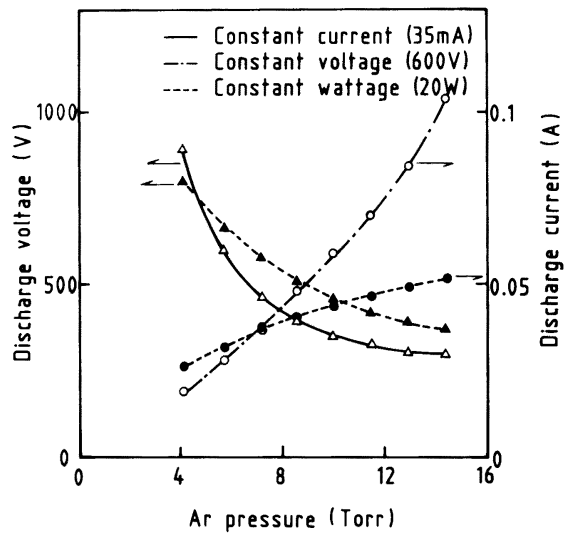

Fig. 2. Relation between Ar pressure and discharge voltage/discharge current of $85 \% \mathrm{Zn}-15 \% \mathrm{Fe}$ alloy.

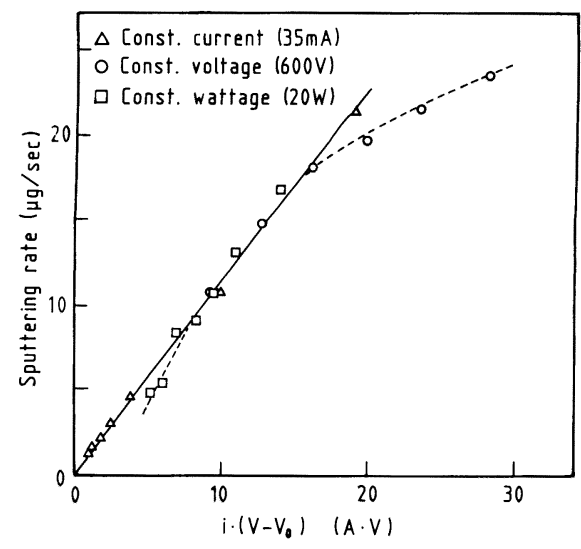

Fig. 3. Relation between discharge characteristics (current and voltage) and sputtering rate of $85 \% \mathrm{Zn}-15 \%$ Fe alloy.

GDSに扔けるスパッ夕速度 $v$ が放電電流 $i$ と放電電 圧 $\left(V-V_{0}\right)$ （ただし $V_{0}$ はスパッ夕しきい電圧）の積に 比例することは, BOUMANS ${ }^{6)}$ をはじめ多数の研究者に よつて報告されている. Fig. 3 は, Ar 圧を変えること によつて,下層めつき層 $(85 \% \mathrm{Zn}-15 \% \mathrm{Fe})$ の平均スパッ 夕速度と, 放電電流および電圧とが变化する関係を示し たものであるが，定電圧および定電力放電の一定 Ar 圧 (10 Torr) 以上を除くと, 本試料のスパッ夕速度 $v$ $(\mu \mathrm{g} / \mathrm{s}$, 本報告では $4 \mathrm{~mm} \phi$ の放電域のスパッ夕重量で表 示）は，放電モードや Ar 圧とは無関係に（4）式で書 きあらわされる。

$$
v=k \cdot i \cdot\left(V-V_{0}\right)
$$

ここで $i$ は放電電流 $(\mathrm{A}), \quad V$ は放電電压 $(\mathrm{V}), V_{0}$ はス パッタしきい電压 $(\mathrm{V}), k$ は定数（単位電流・電压当た りのスパッ夕速度) である. 本試料の $V_{0}$ は約 $260 \mathrm{~V}$ で, $k$ は $1.15\left(\mu \mathrm{g} \cdot \mathrm{s}^{-1} \cdot \mathrm{A}^{-1} \cdot\left(V-V_{0}\right)^{-1}\right)$ であつた。

Fig. 3 で，（4）式からのずれの大きい定電圧の高 Ar 压側 (10 Torr 以上) は, 放電電流の高い領域 $(i \geq$ $50 \mathrm{~mA}$ ，定電力の 13 Torr 以上も同様）である。この領 域における放電では, 陰極からの二次電子放出が増加し, スパッタリングに有効なイオン電流に加算されて, 見か け上大きな電流が検出されていることに起因していると 考えられる. Fig. 4 に同じく下層めつき層の Zn および $\mathrm{Fe}$ の発光収率と $\mathrm{Ar}$ 压との関係を示す。定電圧放電な らびに定電力放電では, Ar 圧の上昇とともに Zn およ び Fe のスペクトルの発光収率も増大するのに対して, 定電流放電では 11.5 Torr が極大点となつた。発光収 率の $\mathrm{Ar}$ 圧依存性が他と異なる定電流の高 $\mathrm{Ar}$ 压側の放 電は, スパッタしきい電圧に近い低電圧領域（Fig. 2, 


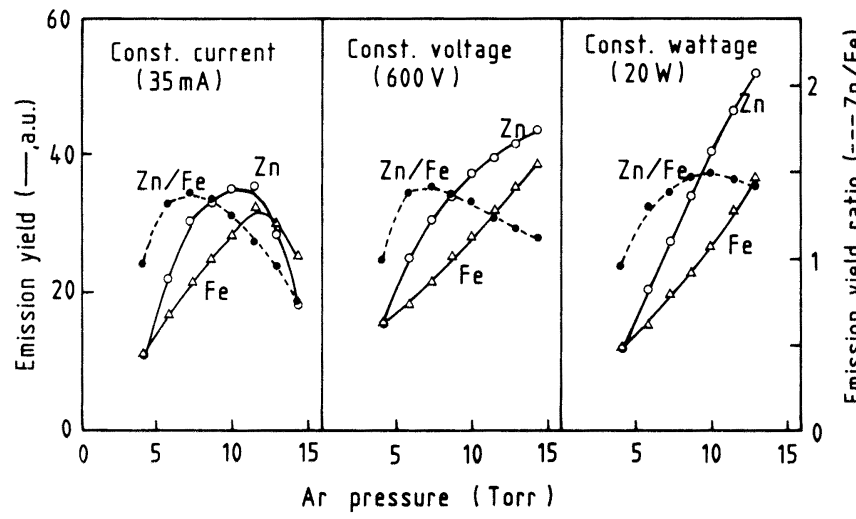

Fig. 4. Relation between Ar pressure and emission yield/emission yield ratio of $\mathrm{Zn}$ and $\mathrm{Fe}$ in $85 \% \mathrm{Zn}-15 \% \mathrm{Fe}$ alloy.

$300 \mathrm{~V}$ 以下）であり，正常グロー放電に近く（あるいは そのもの), 異常グロー放電領域にある他の放電とはプ ラズマ温度等発光に関りする諸条件が異なつていること によると考えられる，発光收率の高い放電領域をスパッ 夕速度でみると，尘電流では遅い領域であるのに対して， 定電压抢よび走電力放電では速い領域と逆の傾问にあ る。したがつて，定電げならびに分電力放電は，スパッ 夕速度と発光收率の相乗効果による高感度な分析が期待 できる。‥方，非常に薄い皮膜の分析に対しては，兟電 流の低スパッ夕速度の領域（高 Ar 性）の放電が存効に なる川能性がある。

Fig. 4 にホされる Zn と Feの発光収率の比（相対発 光收率) の Ar 依存性（放電電流あるいは電压依传性 ともいえる) は、いずれの放電モードも緩い極大点が現 れ，その近傍で変化が小さくなつている，相対発光収率 が放電条件の影響を受けないということは，足量化にと つて重要な要素となる。

\section{$3 \cdot 2$ マトリックス効果}

以上述べた检期は，同一組成の試料に対して，Ar 月： を変えることによつて放電特性を変えて得られた結果で

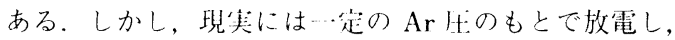
試料組成が変わることによつて放電条件が変動する。こ の試料組成に依仔した放電条件（電流，軋居）の变化(マ トリックス効果) を，Ar 居を変えた測定で得られた放 電条件と諸特性の関係から整理できるものかどうか, 疑 問が残る。そこで, 組成の巽なる $\mathrm{Zn}-\mathrm{Fe}$ 今金単屖めつ き材を使つて，间一条作で放電したときの電流，電压， スパッ夕速度および発光收率について等に討した。放電 条件は， $35 \mathrm{~mA}$ 定電流，600 V 起電压抒よび $20 \mathrm{~W}$ 定電 カで, Ar比を6.3 Torr, 7.2 Torr, 8.1 Torrの三水準 とした。

スパッ夕速度に関する梭剧絬果を Fig. 5 に示す。同

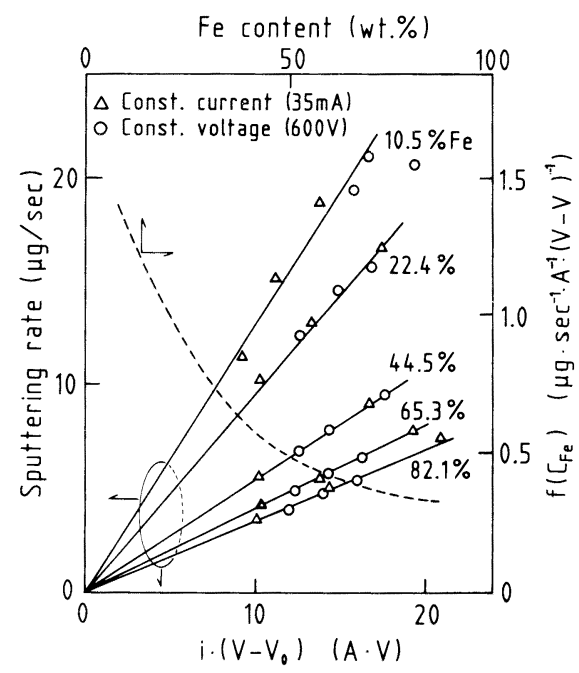

Fig. 5. Relation between discharge characteristics and sputtering rate, and relation between chemical composition and $f\left(C_{\mathrm{Fe}}\right)$ value of $\mathrm{Zn}-\mathrm{Fe}$ alloys.

一試料のスパッ夕速度は、ここでも Ar H:ならびに放電 モードとは無関係に，放電電流 $i$ と電生（ $\left(V-V_{0}\right)$ の積 で整理できる。ただし（4）式の比例定数 $k$ に合金組 成依存性がみられる。したがつて，（4）式はマトリッ クス組成に関する関数 $f(C)$ を使つて（5）式に書き あらわされる。

$$
v=f(C) \cdot i \cdot\left(V-V_{0}\right)
$$

したがつて関数 $f(C)$ を実験的に求めておくことに より，放電の電流，電压から（5）式を使つてスパッ夕 速度を算出することも叮能である.

-...方，合金組成の違いによる放電条件の変動と， $\mathrm{Zn}$ および Feのスペクトル線の発光收率との関係を Fig. 6 に示す。図中の值線は、マトリックスが一起で Ar 圧を 

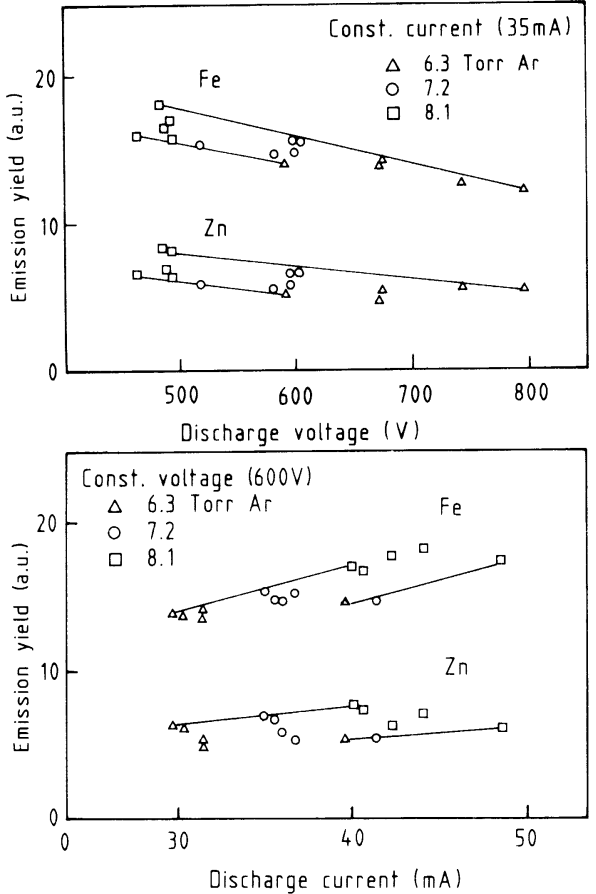

Fig. 6. Relation between discharge voltage/discharge current and emission yield under various $\mathrm{Ar}$ pressures of $\mathrm{Zn}$-Fe alloys.

変えたときの発光收摔の偭问を小寸。マトリックスに起 因した発光收摔の変動にArIミ依你性はほとんど涩めら れないが, 间じくマトリックスに起过した放電電げある いは電流の変動は, Ar 恬によつて異なることが明らか である，定电流放电では，Arl1の高いほど電忙変化が

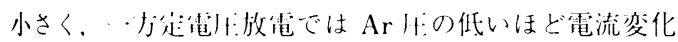
が小さい(この傾们はFig. 1 でも小されている).

BENGTSON は8), Ar l1: 存変えた实験デー夕をもとにマ トリックス效果の補业を行つているが， Zn-Fe 命食の 発光効率の補店にに対しては必ずしも適用できない。

\section{$3 \cdot 3$ 定量分析}

検量線法によるGDSの媣さう们分量分析では，試料 組成とスペクトル溞度拉よびスパッ夕速度との関係を基 準試料を使つてあらかじめ求めておき，この検量線をも とに未知試料のスペクトル線搔度から糺成を求め, さら にスパッ夕深さに変換する，検星線法は，マトリックス 効果を考虑する必装のないことを特产とするが，‥万力， 組成が深さ力们でダイナミックに変化する場令には、三 元素以上の多成分系の検荲線の作成そのものが困難なた
め，適用範讲が限られてくる。‥万，光強度積分法によ る定量法は，各元素のスペクトル線の発光収率を実験的 に求めておき，末知試料の測定に扔ける単位時間ごとの スペクトル線強度を直接スパッ夕重量に変換しこの元 素ごとのスパッ夕重量から組成とスパッ夕深さを求める (式 $(6) \sim(8))$.

$$
\begin{aligned}
& \Delta W_{i}=I_{i} \cdot \Delta t / R_{i} \cdots \\
& \Delta d=\sum_{i}\left(\Delta W_{i} / \rho_{i}\right) \\
& C_{i}=\Delta W_{i} / \sum_{i} \Delta W_{i}
\end{aligned}
$$

$\Delta W_{i}: \Delta t \mathrm{~s}$ にスパッタされる $i$ 元素の重量 $(\mathrm{g})$

$I_{i}: \Delta t \mathrm{~s}$ の $i$ 元素のスペクトルの平均強度 $(\mathrm{V})$

$R_{i}: i$ 元素のスペクトルの発光収率 $\left(\mathrm{V} \cdot \mathrm{s} \cdot \mathrm{g}^{-1}\right)$

$\Delta d: \Delta t \mathrm{~s}$ のスパッ夕深さ

$\rho_{i}: i$ 元素の密度

$C_{i}: i$ 元素の含有率

光強度積分法は原理的に合金あるいは同時に定量する元 素数の制約を受けない便利な方法であるが，適用にあた つて注意すべき点は，本法の前提条件となつている「発 光収率がマトリックス組成の影響を受けない」が成り立 つことを確認することである。

$\mathrm{Zn}-\mathrm{Fe}$ 令金の場合にこの前提条件が綮密には成り立 たないことはFig. 6 に示されている。そこで,この実 験事実を無視して一定の発光効率で定量した際に生ずる 䛊差について以下に考察する．Fig. 7 はFig. 6 の結果 を合金組成と発光収率の関係で書き直し，新たに純鉄と 純带鉛のデー夕を追加したものである，Zn，Feのスペ クトルともに発光収率の組成依存性が認められ, Fe 濃 度が高くなるほど，すなわちスパッ夕速度が小さくなる

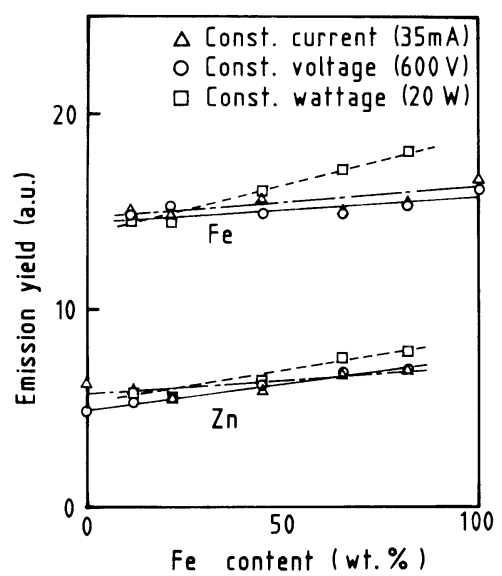

Fig. 7. Relation between chemical composition of $\mathrm{Zn}-\mathrm{Fe}$ alloys and emission yield. 
Table 3. Comparision of sputtering, light emission and discharge parameters between $\mathrm{TiH}_{2}$ and Ti layers.

\begin{tabular}{l|lc|cc}
\hline \multirow{2}{*}{} & \multicolumn{2}{|c|}{$\begin{array}{c}\text { Constant } \\
\text { voltage }\end{array}$} & \multicolumn{2}{c}{$\begin{array}{c}\text { Constant } \\
\text { current }\end{array}$} \\
\cline { 2 - 6 } & $\mathrm{TiH}_{2}$ & $\mathrm{Ti}$ & $\mathrm{TiH}_{2}$ & $\mathrm{Ti}$ \\
\hline Sputtering rate $(\mu \mathrm{g} / \mathrm{s})$ & 1.3 & 4.2 & 1.6 & 3.9 \\
Light intensity of $\mathrm{Ti}$ II $337.3 \mathrm{~nm}$ & 2.56 & 8.84 & 3.01 & 1.74 \\
Emission yield of Ti II $337.3 \mathrm{~nm}$ & 2.0 & 2.1 & 2.0 & 0.47 \\
Voltage $(\mathrm{V})$ & \multicolumn{2}{|c}{600} & 904 & 584 \\
Current $(\mathrm{mA})$ & 54.1 & 81.9 & \multicolumn{2}{|c}{50.0} \\
\hline
\end{tabular}

ほど発光収率が大きくなつている，定電力放電は定電流 および定電圧放電に比較して, 発光収率の組成依存傾向 がより強く現れている.

$\mathrm{Zn}$ 㧍よび $\mathrm{Fe}$ 濃度が 0 〜 $100 \%$ まで変化した際の発 光収率の変動（相対值）は, $\mathrm{Fe}$ で約 10\%, Zn で約 $40 \%$ になる。これらの值が，発光収率を一定として（4) 式 から求められるスパッ夕重量の誤差となる。一方，組成 計算で生ずる䛊差は, $\mathrm{Zn}$ と $\mathrm{Fe}$ の発光収率の求め方に よつても異なるが（純鉄，純要鉛の発光収率を使うと誤 差が大きい), 相対値で約 $10 \%$ 以下には納まる.しかし， より正確な分析を期するためには，発光收率の組成依存 性をあらかじめ調べておき，発光効率を組成の関数とし て補正すればよい，管理分析のように，分析対象組成が 常に一定している場合には，実際の素材に近い組成の発 光収率を使うことにより高精度な分析が可能となろう。

Fig. 6 㧍よび 7 に示される結果からは，定電流放電 と定電圧放電とに有意差がほとんどみられない。一方， $\mathrm{Fe} ， \mathrm{Ni}$ 扩よび $\mathrm{Cr}$ の 10 100\% の濃度範囲における各 元素の発光収率の実験值は, 定電圧放電の $\pm 5 \%$ の変 動（相対值）に対して，定電流放電はより大きい変動 ( $\mathrm{Ni}: \pm 10 \%, \mathrm{Cr}: \pm 20 \%)$ が認められばらつきも大き かつた ${ }^{9)}$.また定電圧放電は, $\mathrm{Fe}$ 金属状態と酸化物, $\mathrm{Ti}$ の金属状態と水素化物の間でも, $\mathrm{Fe}$ 拉よび $\mathrm{Ti}$ のス ペクトルの発光収率に良好な一致をみている. Table 3 に $\mathrm{Ti}$ と $\mathrm{TiH}_{2}$ の例を示す。筆者らは GDSに招ける発 光収率に対して, 放電電流よりも電圧の方がより支配的 と考え, 光強度積分法による深さ方向定量分析に際して は定電压放電法を採用している.

\section{4. 薄膜への適用}

表面分析における GDSは，非常に速いスパッ夕速度 が得られることから，厚い皮膜の組成を短時間で分析で きることが最大の特長と言えるが，一方，放電は立ち上 がり初期から安定しており, 表面層の薄膜の分析も叮能 である．計算上の深さ分解能（スパッ夕速度とデー夕採

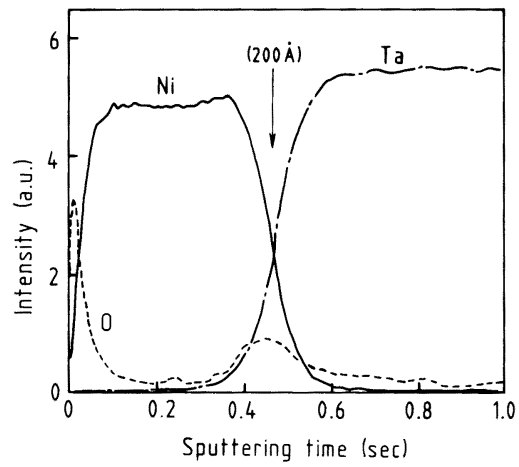

Fig. 8. Depth profile Ni evaporated layer.
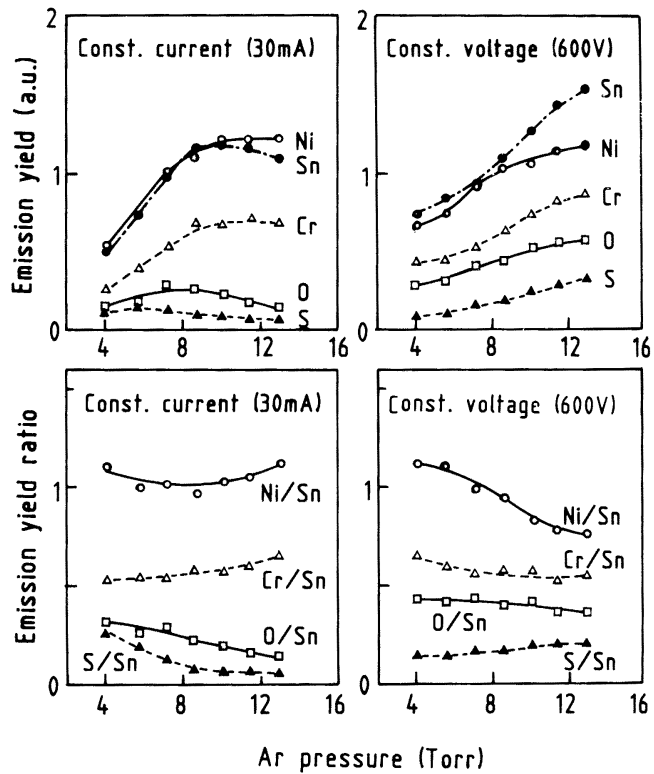

Fig. 9. Relation between Ar pressure and emission yield/ emission yield ratio of $\mathrm{Sn}, \mathrm{Ni}, \mathrm{Cr}, \mathrm{O}$ and $\mathrm{S}$ in $\mathrm{Sn}$ plated layer.

取間隔の間係）は原子吘オーダーになる。ちなみに Ta 基板上に蒸着された $\mathrm{Ni}$ 皮膜（化学分析結果から厚さは 約 $20 \mathrm{~nm}$ ) の測定結果を Fig. 8 に示す.

溶接缶 (食午) 用 Snめつき材は各社とも薄目付化 ( $0.8 \mathrm{~g} / \mathrm{m}^{2}$, 約 $\left.100 \mathrm{~nm}\right)$ が指向され, 溶接性向上のため の $\mathrm{Ni}$ 等による下地処理と, 酎食性向上のためのクロ メート処理が施される。したがつて表面の皮膜は二層ま たは三層構造になつているが， $\mathrm{Ni}$ 層 (リフロー前) と クロメート層は非常に薄い（Table 1)。これらの皮膜 の深さ方向定量分析を, GDSの光強度積分法により検 


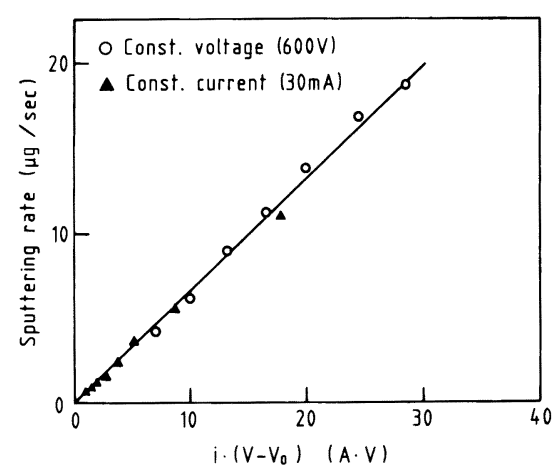

Fig. 10. Relation between discharge characteristics and sputtering rate of Sn platd layer.

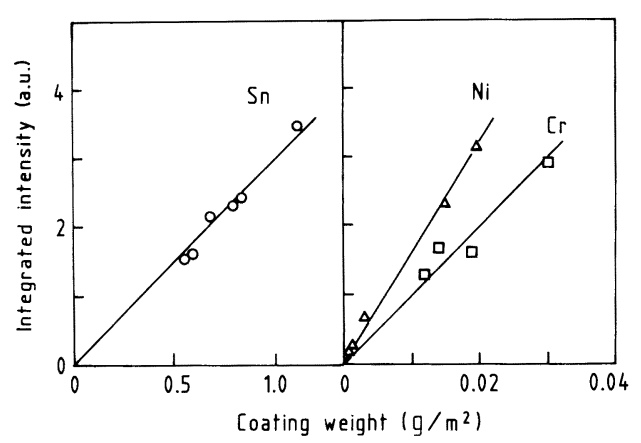

Fig. 11. Relation between coated weigth of $\mathrm{Sn}, \mathrm{Ni}$ and $\mathrm{Cr}$ and integrated intensity.

討した.

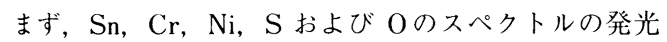
收率の Ar 压依你性を Fig. 9 に示す。 Zn-Fe 合金同様 RAr压の高い領域で発光收率も高くなつている.一方, $\mathrm{Sn}$ に対する $\mathrm{Cr}, \mathrm{Ni}, \mathrm{S}$ 抒よび $\mathrm{O} の$ 相対発光収率は, 一部を除いて Ar 压が 10 Torr 近傍でほぼ安定する。 めつき層のスパッ夕速度の放電条件依存性も, $\mathrm{Zn}-\mathrm{Fe}$ 合金と同様に（1）式の電流と電压の関数で整理できる (Fig. 10).

$600 \mathrm{~V}$ の分電的放電で, 7.2 Torr の Ar 压（Sn 層の スパッ夕速度約 $100 \mathrm{~nm} / \mathrm{s}$ ) に㧍ける $\mathrm{Sn}, \mathrm{Cr}$ および $\mathrm{Ni}$ のスペクトルの稓分強度とスパッ夕重量との関係を Fig. 11 に亦す。この結果から各元素のスペクトルの単 位重量当たりの発光量を求め, これを定量化のための発 光収率とした。

Fig. 12 に試料 $\mathrm{L} の$ GDS 測定プロフィルと、これを 深さと元素濃度に変換したプロフィルを示す。厚み約
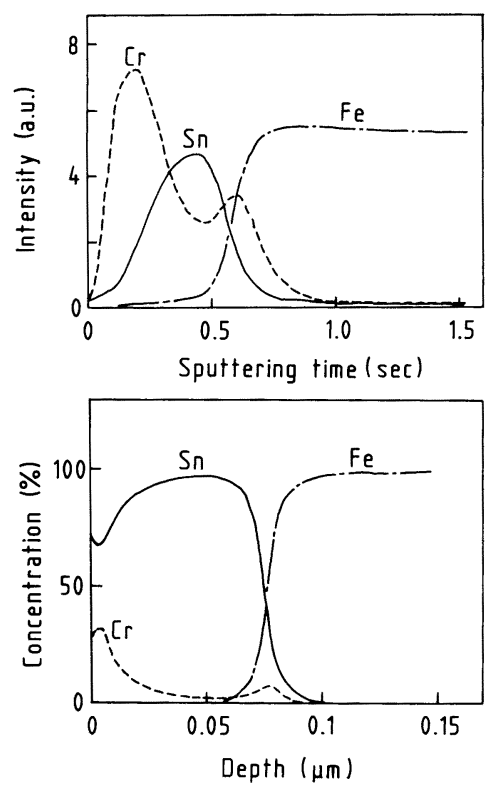

Fig. 12. Depth profiles of Sn plated layer.
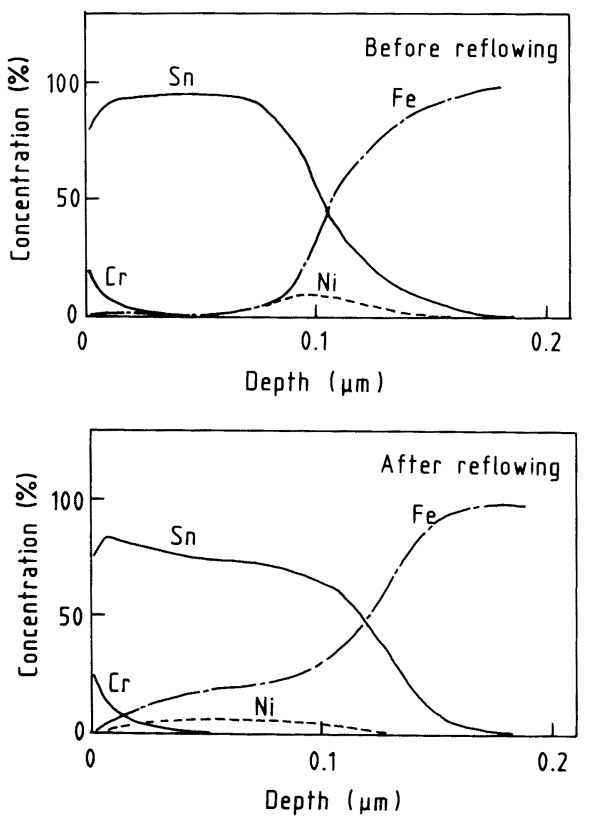

Fig. 13. Depth profiles of Sn plated layer.

$75 \mathrm{~nm}$ のめつき層は, $0.6 \mathrm{~s}$ 程度でスパッ夕されてしま うが良好な深さ方向分解能が得られている.グロー放電 における Ar イオンは, 放電管内の圧力が高いためにそ の粒子との衝突のくり返しによつてエネルギーが次第に 
Table 4. Repeatability of Sn plated layers $(n=10)$.

\begin{tabular}{|c|c|c|c|c|c|}
\hline Sample & & $\mathrm{L}$ & & $\mathrm{K}$ & \\
\hline Element & Sn & $\mathrm{Cr}$ & Sn & $\mathrm{Ni}$ & $\mathrm{Cr}$ \\
\hline Chemical analysis & $0.60 \mathrm{~g} \mathrm{~m}^{2}$ & $0.030 \mathrm{~g} \mathrm{~m}^{2}$ & $1.12 \mathrm{~g} \mathrm{~m}^{2}$ & $0.20 \mathrm{~g} / \mathrm{m}^{2}$ & $\ldots$ \\
\hline $\begin{array}{r}\bar{X} \\
\sigma \\
\mathrm{CV}(\%)\end{array}$ & $\begin{array}{l}0.58 \\
0.024 \\
4.2\end{array}$ & $\begin{array}{l}0.033 \\
0.002 \\
4.6\end{array}$ & $\begin{array}{l}1.22 \\
0.059 \\
4.8\end{array}$ & $\begin{array}{l}0.20 \\
0.007 \\
3.5\end{array}$ & $\begin{array}{l}0.008 \\
0.0004 \\
5.0\end{array}$ \\
\hline
\end{tabular}

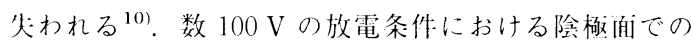
$\mathrm{Ar}$ イオンのエネルギーは 100 - $200 \mathrm{eV}$ 程度になり，し たがつて人射イオンによるアトミック・ミキシングがほ とんど無視できるため表而層の深さ方们分解能が優れて いるものと推:尘される．Fig. 13 に $\mathrm{Ni}$ 下地処理した $\mathrm{Sn}$ めつき材(試料I)のリフロー処理前後の GDS プロフィ ルを示す。リフロー処理によつて下地の Fe がめつき層 に拡散（命金を生成）し，また， $\mathrm{Ni} も \mathrm{Sn}$ 層に拡散し ている様子が明瞭に現われている。試料 $\mathrm{K}$ およびLにつ いて, 10回くり这し測定の分析精度を Table 4 に示す. $\mathrm{Sn}, \mathrm{Cr}$ および Ni のくり返し分析精度は変動係数で約 $5 \%$ であつた。

\section{5. 結}

\section{言}

GDSによる鋼板表面皮膜の深さ力问起量分析に関し て，放電特性と発光収摔拐よびスパッ夕速度等について 検討し以下の䌃論を得た。

1) 同一組成マトリックスのスパッ夕速度は, $\mathrm{Ar}$ 压 および放電モードとは無関係に，放電電流と電仕の積に
比例する.

2) 異常グロー放電領域に损ける発光收摔は, Ar 压 の上昇とともに増大する。

3) Zn-Fe 今金の $\mathrm{Zn}$ 抢よび $\mathrm{Fe}$ のスペクトルの発光 收率にマトリックス效果が恋められる。したがうて，光 強度積分法による $\mathrm{Zn}-\mathrm{Fe}$ 个食めつき雷の超荲にあたつ ては，発光收摔の氿めわに注㥿を妆する。

4) GDSは，クロメート支膜等非常に溥い皮膜の定 量分析をも父分に行うことができる。全少みが $100 \mathrm{~nm}$ 以下の $\mathrm{Ni}, \mathrm{Sn}$ 扩よび $\mathrm{Cr}$ (クロメート) からなる多層 構造皮膜のくり返し分析精度は，变動係数で5\%以下 であつた。

\section{文献}

1) 古主泰子，人橋善治：鉄と銅，69 (1983)，S1052

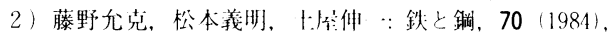
$\mathrm{S} 1045$

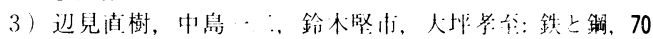
(1984), S 296

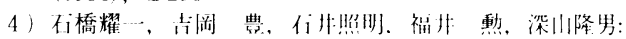
鉄と鋼，70 (1984)，S 1044

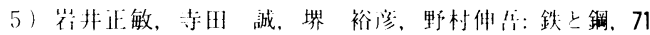
(1985), S 1214

6) P. W. J. M. Boumans: Anal. Chem., 44 (1972), p. 1219

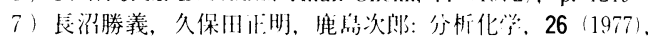
p. 25

8) A. Bengitson: Spectrochim. Acta, 40B (1985), p. 631

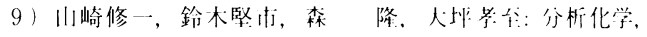
35 (1986), p. 673

10) W. D. Davis and T. A. Vanilkssick: Physical Review, 131 (1963), p. 219 